\title{
Expert
}

Jurnal Management Sistem Informasi dan Teknologi

\section{Aplikasi Absensi Berbasis Android Menggunakan Validasi Kordinat Lokasi Dan Nomor Handpone Guna Menghindari Penularan Virus \\ Covid 19}

\author{
Dani Yusuf, Freddy Nur Afandi \\ Program Studi Informatika \\ Universitas Bhayangkara Jakarta Raya \\ STMIK Tunas Bangsa \\ Bekasi, Indonesia \\ Bandar Lampung, Indonesia \\ dani.yusuf@dsn.ubharajaya.ac.id
}

\begin{abstract}
Abstrak-Hampir semua institusi memerlukan data kehadiran karyawan, data kehadiran ini penting untuk dikelola karena data kehadiran digunakan untuk keperluan pembayaran gaji, insentif, disamping untuk keperluan tersebut pencatan kehadiran diperlukan juga untuk laporan kehadiran suatu kegiatan di luar kantor, sekolah, kampus dan sebagainya. Saat ini teknologi android semakin berkembang dan salah satu fitur dari perangkat smartphone android adalah google map yang dapat mengetahui lokasi kordinat dan nomor handphone penggunanya apabila fitur location dan telephone diaktifkan. Saat ini sedang mewabah penyakit yang disebabkan oleh virus covid 19, dan telah menyebar ke beberapa negara secara cepat, termasuk Indonesia. Salah satu sumber penyebarannya adalah sentuhan jari dan tangan yang penggunaanya secara bersama seperti saat melakukan absen menggunakan mesin absensi melalui sidik jari. Berdasarkan permasalahan tersebut, memunculkan gagasan bagi penulis untuk membuat suatu aplikasi absensi berbasis android. Metodologi perancangan perangkat lunak menggunakan metode prototype. Bahasa pemrograman yang digunakan adalah PHP untuk backend dan Java untuk frontend kemudian untuk penyimpanan databasenya menggunakan MySQL. Berdasarkan hasil penelitian dan pembahasan yang telah penulis lakukan, maka dapat ditarik kesimpulan bahwa dengan adanya Sistem Absensi Berbasis Android Menggunakan Validasi Kordinat Lokasi Dan Nomor Handpone ini dapat mempermudah pendataan kehadiran karyawan dan dapat mencegah penyebaran virus covid 19 melalui mesin absensi, rekap absensi menjadi lebih mudah dan data kehadiran dapat dilihat secara realtime.
\end{abstract}

Kata kunci : sistem absensi android, kordinat, handphone

\section{Pendahuluan}

Pengertian Android adalah sistem operasi yang dirancang oleh Google dengan basis kernel Linux untuk mendukung kinerja perangkat elektronik layar sentuh, seperti tablet atau smartphone. Hampir semua orang dewasa memiliki dan menggunakan handphone android ini mulai dari komunikasi, hiburan, belanja, transportasi dan sebagai alat bantu dalam mencari suatu lokasi berdasarkan kordinat tempat asal dan tempat tujuan. Android bersifat opensource atau bebas digunakan, dimodifikasi, diperbaiki dan didistribusikan oleh para pembuat ataupun pengembang perangkat lunak. Dengan sifat opensource perusahaan teknologi bebas menggunakan OS ini diperangkatnya tanpa lisensi alias gratis.

Begitupun dengan para pembuat aplikasi, mereka bebas membuat aplikasi dengan kode-kode sumber yang dikeluarkan google. Dengan seperti itu android memiliki jutaan support aplikasi gratis/berbayar yang dapat diunduh melalui google play. Hampir semua institusi memerlukan data kehadiran karyawan, data kehadiran ini penting untuk dikelola karena data kehadiran biasanya digunakan untuk keperluan pembayaran gaji, insentif, disamping untuk keperluan tersebut pentatan kehadiran diperlukan juga untuk laporan kehadiran suatu kegiatan di luar kantor, sekolah, kampus dan sebagainya. Saat ini teknologi android semakin berkembang dan salah satu fitur dari perangkat smartphone android adalah google map yang dapat mengetahui lokasi kordinat dan nomor handphone penggunanya apabila fitur location dan telephone diaktifkan. Saat ini sedang mewabah penyakit yang disebabkan oleh virus covid 19, dan telah menyebar ke beberapa negara secara cepat. Salah satu sumber penyebarannya adalah sentuhan jari dan tangan yang penggunaanya secara bersama seperti saat melakukan absen menggunakan mesin absensi melalui sidik jari. Berdasarkan permasalahan tersebut, memunculkan gagasan bagi penulis untuk membuat suatu aplikasi berbasis andrond agar para karyawan dapat melakukan absensi melalui perangkat handpone masing-masing sehingga. Metodologi perancangan perangkat lunak menggunakan metode prototype dengan tahapan pengumpulan kebutuhan, membangun prototyping, evaluasi protoptyping, mengkodekan system, menguji sistem, evaluasi sistem, menggunakan sistem. Bahasa pemrograman yang digunakan adalah PHP untuk backend dan Java untuk frontend dan untuk penyimpanan databasenya menggunakan MySQL. Berdasarkan hasil penelitian dan pembahasan yang telah penulis lakukan, maka dapat ditarik kesimpulan bahwa dengan adanya sistem absensi berbasis android 


\section{Expert}

menggunakan validasi kordinat lokasi dan nomor handpone ini dapat mempermudah pendataan kehadiran karyawan dan dapat mencegah penyebaran virus covid 19 yang sedang mewabah apabila para karyawan menggunakan mesin absensi sidik jari yang kemungkinan membawa virus dari salah satu karyawannya, rekap absensi menjadi lebih mudah dan data kehadiran dapat dilihat secara realtime.

\subsection{Rumusan Masalah}

Berdasarkan latar belakang yang telah diuraikan, rumusan masalahnya adalah "Bagaimana membuat aplikasi berbasis android menggunakan validasi kordinat lokasi dan nomor handphone pengguna yang dapat memudahkan karyawan dalam melakukan absensi kehadiran?

\subsection{Tujuan dan Manfaat Penelitian}

\section{a. Tujuan Penelitian}

Tujuan dari penelitian ini adalah sebagai berikut :

1. Menghindari kontak langsung antara karyawan satu dengan lainnya pada saat melakukan absen masuk dan pulang.

2. Mempermudah bagian kepegawaian dalam mendata kehadiran karyawan.

\section{b. Manfaat Penelitian}

Adapun manfaat dari Penelitian ini adalah sebagai berikut:

1. Mengurani penyebaran virus corona dari segi absensi, karena tidak adanya kontak fisik pemakaian mesin absensi secara bersamasama yang berpotensi menularkan virus covid 19.

2. Mempercepat proses laporan kehadiran karyawan karena data absensi diperoleh scara realtime.

\section{Landasan Teori}

Menurut salah satu ahli yaitu Hengky W. Pramana, pengertian aplikasi adalah suatu perangkat lunak yang dibuat khusus untuk memenuhi kebutuhan berbagai aktivitas dan pekerjaan, misalnya; pelayanan masyarakat, aktivitas niaga, periklanan, game, dan berbagai aktivitas lainnya. Berdasarkan pengertian tersebut, maka penulis menyimpulkan bahwa Apa yang dimaksud dengan aplikasi (application)? dalam ilmu komputer, pengertian aplikasi adalah suatu perangkat lunak atau program komputer yang beroperasi pada sistem tertentu yang diciptakan dan dikembangkan untuk melakukan perintah tertentu.

Pengertian Android

Android merupakan sistem operasi yang digunakan untuk perangkat mobile berbasis Linux. Pada awalnya sistem operasi ini dikembangkan oleh Android.Inc, yang kemudian dibeli oleh Google pada tahun 2005. Android mengembangkan usaha pada tahun 2007 dibentuklah Open Handset Alliance (OHA), sebuah konsorsium dari beberapa perusahaan, yaitu Texas Instrument, Broadcom Corporation, Google, HTC, Intel, LG, Marvell Technology Group, Motorola, Nvidia, Qualcom, Samsung Electronics, Sprint Nextel, dan T-Mobile dengan tujuan untuk mengembangkan standar terbuka untuk perangkat mobile Smartphone.

Sistem koordinat Kartesius dalam dua dimensi umumnya didefinisikan dengan dua sumbu yang saling bertegak lurus antar satu dengan yang lain, yang keduanya terletak pada satu bidang (bidang $x y$ ). Sumbu horizontal diberi label $x$, dan sumbu vertikal diberi label $y$. Pada sistem koordinat tiga dimensi, ditambahkan sumbu yang lain yang sering diberi label $z$. Sumbu-sumbu tersebut ortogonal antar satu dengan yang lain. (Satu sumbu dengan sumbu lain bertegak lurus.)

Titik pertemuan antara kedua sumbu, titik asal, umumnya diberi label 0 . Setiap sumbu juga mempunyai besaran panjang unit, dan setiap panjang tersebut diberi tanda dan ini membentuk semacam grid. Untuk mendeskripsikan suatu titik tertentu dalam sistem koordinat dua dimensi, nilai $x$ ditulis (absis), lalu diikuti dengan nilai $y$ (ordinat). Dengan demikian, format yang dipakai selalu $(x, y)$ dan urutannya tidak dibalik-balik.

\section{Metodologi Penelitian}

3.1 Metodologi Perancangan Sistem

Metode perancangan sistem yang digunakan penulis adalah metode prototype. Metodologi perancangan perangkat lunak menggunakan metode prototype dengan tahapan sebagai berikut:

1. Pengumpulan Kebutuhan

2. Membangun Prototyping

3. Evaluasi Protoptyping,

4. Mengkodekan Sistem,

5. Menguji Sistem,

6. Evaluasi Sistem,

7. Menggunakan Sistem.

Bahasa pemrograman yang digunakan adalah PHP untuk backend dan Java untuk frontend kemudian untuk penyimpanan databasenya menggunakan MySQL

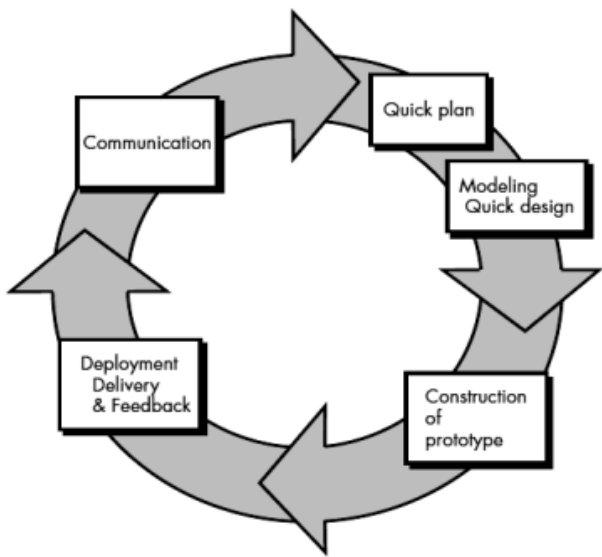

Gambar 1 Alur Metodologi Penelitian

3.2 Analisa dan Perancangan Sistem

1. Analisis Sistem Berjalan

Pelaksanaan kegiatan absensi kehadiran karyawan umumnya dilakukan dengan cara sebagai berikut:

a. Admin mendaftarkan sidik jari karyawan sebagai 


\section{Expert}

identifikasi agar dapat dikenal oleh mesin fingerprint.

b. Setelah sidik jari karyawan dtelah terdaftar, kemudian karyawan menempelkan sidik jari tersebut ke mesin absensi agar dicatat kehadirannya.

c. Begitu juga pada saat pulang kerja, karyawan menempelkan sidik jari ke mesin absensi agar tercatat waktu kepulangannya.

d. Pada periode tertentu (bisa dalam mingguan dan bulanan) Admin akan menarik data abensi dari mesin fingerprint melalui media flashdisk atau media jaringan untuk menudian direkap ke dalam sistem payroll.

2. Analisis Sistem Yang Diusulkan Adapun usulan berdasarkan analisis sistem yang sudah ada adalah sebagai berikut :

a. Didalam aplikasi ini terdapat 3 pengguna yaitu admin, user dan supervisor.

b. Admin akan membuat laporan baru dengan memasukan nama kain, warna kain dan standar pengetesan. Selanjutnya akan mendapatkan nomor laporan pengetesan secara otomatis sesuai dengan urutan pengetesan yang dibuat.

c. User hanya diberi akses untuk menginput nilai pengetesan kain tekstil saja tanpa mampu untuk merubah identitas kain tersebut. User akan diberi nomor laporan pengetesan oleh admin yang nantinya pada aplikasi ini akan dibuka dengan memasukan nomor pengetesan tersebut.

3.3 Perancangan Sistem

Use Case Diagram

Berikut gambar use case diagram sistem aplikasi absensi berbasis android menggunakan validasi kordinat lokasi dan nomor handpone seperti telihat pada gambar berikut:

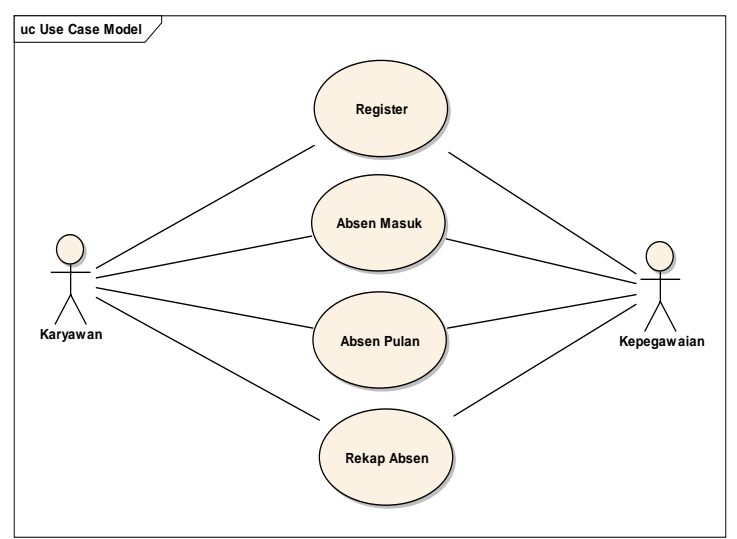

Gambar 2 Diagram Use Case Diagram

\section{Activity Diagram}

Berikut adalah diagram yang menjelaskan aktivitas karyawan dalam melakukan absen menggunakan perangkat handphone android.

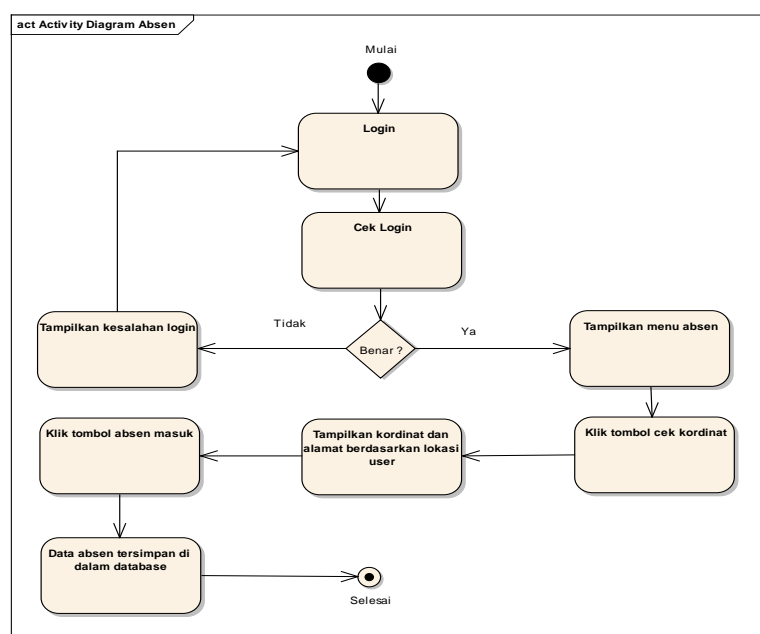

Gambar 3 Diagram Activity Diagram Admin

\section{Sequence Diagram}

Berikut adalah diagram yang menjelaskan urutan karyawan dalam melakukan absen menggunakan perangkat handphone android seperti terlihat pada gambar di bawah ini.

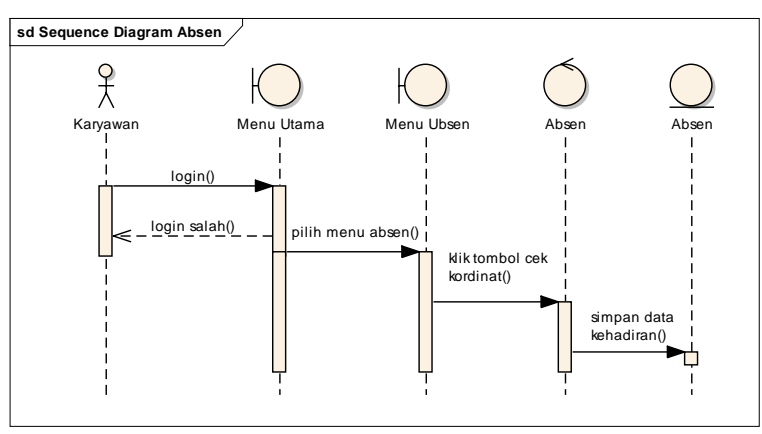

\section{Gambar 4. Sequence Diagram absensi}

\section{Class Diagram}

Berikut adalah class diagram yang digunakan pada sistem absensi berbasis android menggunakan validasi kordinat dan nomor handphone user.

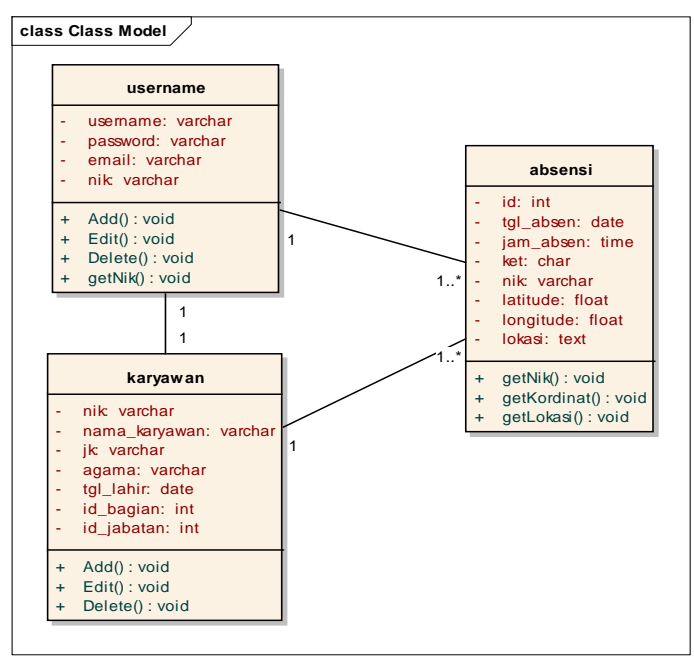




\section{Expert}

\section{Gambar 5 Class diagram}

\section{Hasil Dan Pembahasan}

4.1 Perangkat Lunak

Perangkat lunak yang digunakan pada sistem aplikasi absensi berbasis android menggunakan validasi kordinat lokasi dan nomor handpone adalah sebagai berikut:

1. Sistem Operasi Windows 7 Profesional.

2. Android Studio 3.4

3. XAMPP 7.3 (Apache, PHP, MySQL)

4. $\quad$ Notepad ++ v6.8.9

5. Browser Mozile Firefox dan CROME.

\subsection{Perangkat Keras}

Spesifikasi perangkat keras minimum yang dibutuhkan untuk menjalan aplikasi ini adalah berikut.

1. Prosesor : Kecepatan minimum 1.8

GHZ

2. RAM

3. Harddisk

: Minimum $2 \mathrm{~GB}$

GB

4. VGA

: Minimum kapasitas 250

MB

5. Modem

: Kecepatan minimum 32

6. Handphone : Android Kit Kat ke atas

\subsection{Implementasi Antarmuka}

Implementasi antarmuka merupakan hasil dari rancangan antarmuka (interface) adalah sebagai berikut :

\section{Halaman Utama User}

Berikut adalah hasil dari implementasi halaman utama user, halaman ini dapat diakses oleh user setelah aplikasi ini diinstall ke perangkat handphone user.

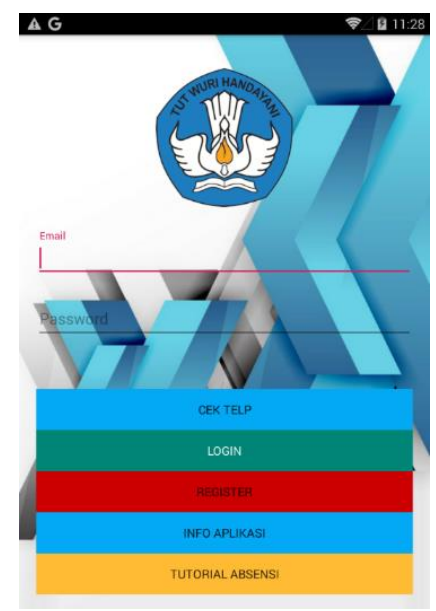

\section{Gambar 6 Menu user}

\section{Halaman Register}

Agar karyawan dapat melakukan absen menggunakan aplikasi ini, maka karyawan tersebut harus melakukan register terlebih dahu, yang nantinya hasil register akan divalidasi oleh bagian kepegawaian. Berikut adalah tampilan implementasi register.

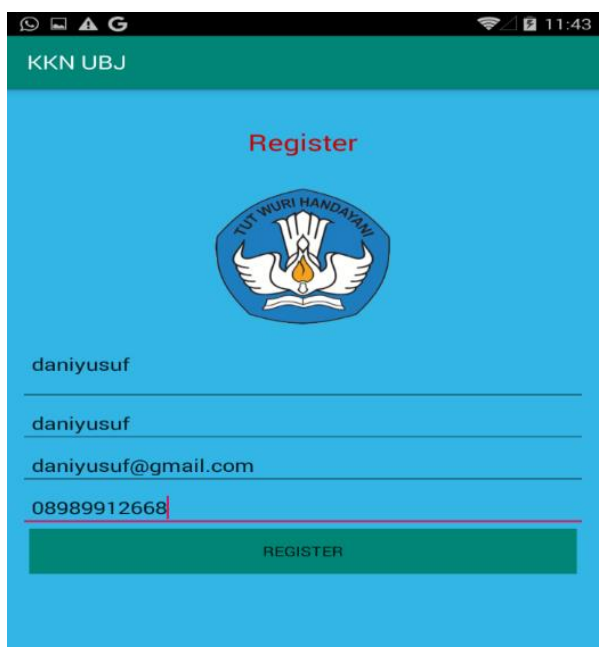

\section{Gambar 7 Register user}

\section{Halaman Form Absensi User}

Setelah karyawan berhasil melakukan login, maka karyawan tersebut dapat melakukan absen melalui handphonenya. Berikut adalah tampilan implementasi absensi.

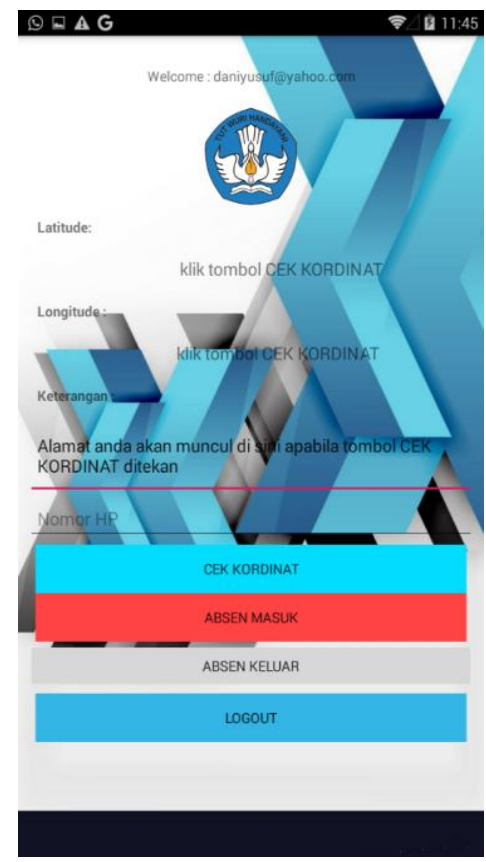

Gambar 8 Diagram Use Case Diagram

\section{Halaman Absensi Karyawan}

Sebelum karyawan dapat melakukan absen dengan cara menekan tombol ABSEN MASUK atau ABSEN KELUAR, karyawan harus menekan tombol CEK KORDINAT terlebih dahulu agar lokasi kordinat, alamat dan nomor handphone karyawan tersebut dapat terdeteksi. Berikut adalah tampilan implementasi setelah lokasi, alamat dan nomor hanphone terdeteksi. 


\section{Expert}

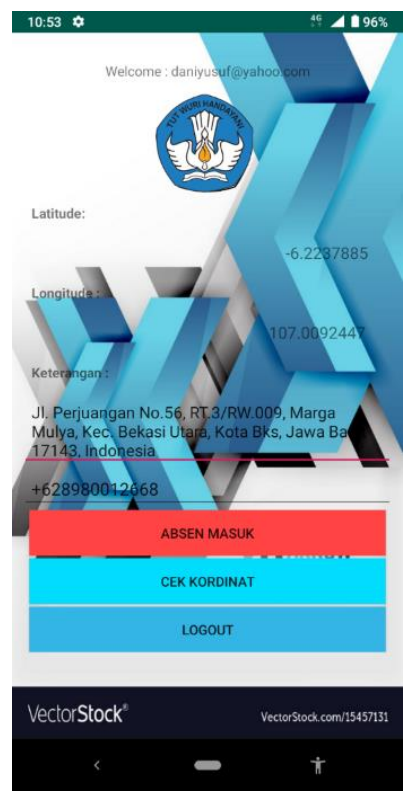

Gambar 9 Diagram Use Case Diagram

\section{Halaman Login Admin}

Halaman login admin ini digunakan oleh admin untuk melakukan login agar dapat masuk ke dalam sistem aplikasi backend. Berikut adalah tampilan implementasi halaman login admin.

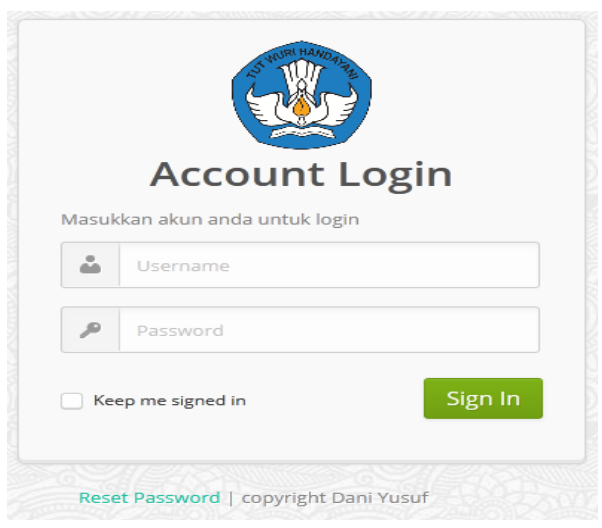

Gambar 10 Halalam login admin

\section{Halaman Utama Admin}

Halaman utama admin fungsinya adalah untuk menampilkan halaman utama admin yang hanya dapat dilihat oleh staff kepegawaian. Berikut adalah tampilan implementasi halaman admin.

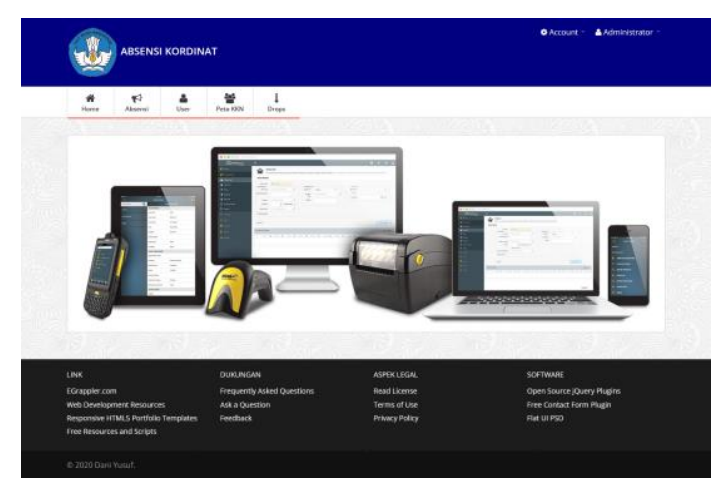

\section{Gambar 11 Menu Utama}

\section{Halaman Absensi Menu Admin}

Halaman absensi menu admin ini fungsinya adalah untuk menampilkan data absensi karyawan yang telah melakukan absensi di aplikasi android. Berikut adalah tampilan implementasi absensi yang dapat dilihat oleh admin bagian kepegawaian.

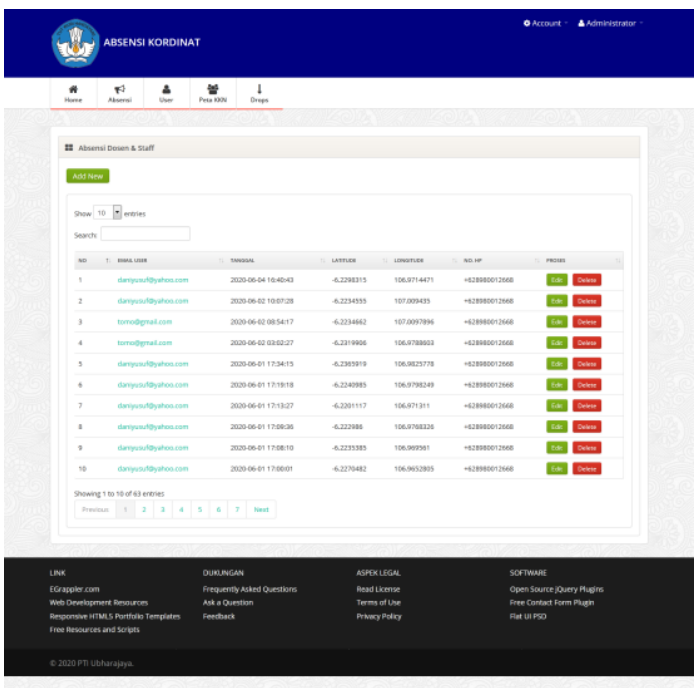

\section{Gambar 12 Halaman hasil absensi karyawan}

\section{Halaman Register}

Agar karyawan dapat melakukan absen menggunakan aplikasi ini, maka karyawan tersebut harus melakukan register terlebih dahulu, yang nantinya hasil register akan divalidasi oleh bagian kepegawaian. Berikut adalah tampilan implementasi register. 


\section{Expert}

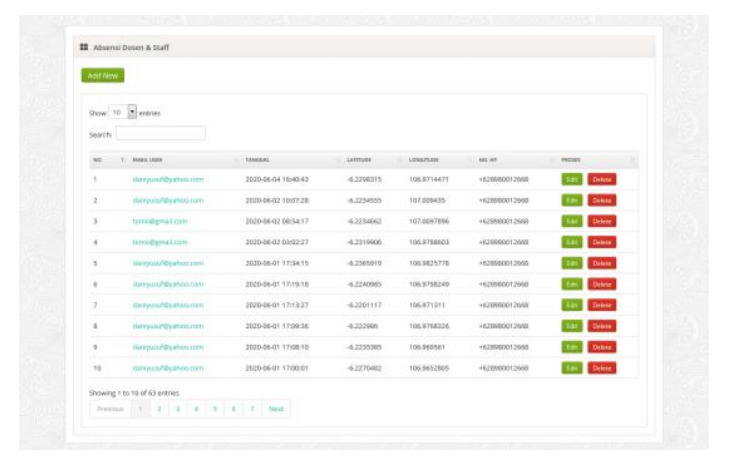

Gambar 13 Halaman register

\section{Halaman Kordinat Karyawan Absen}

Pada halaman ini staff kepegawaian dapat melihat kordinat dan alamat lokasi tempat karyawan melakukan absen kehadiran. Berikut adalah tampilan detail kordinat dan lokasi karyawan saat melakukan absensi.

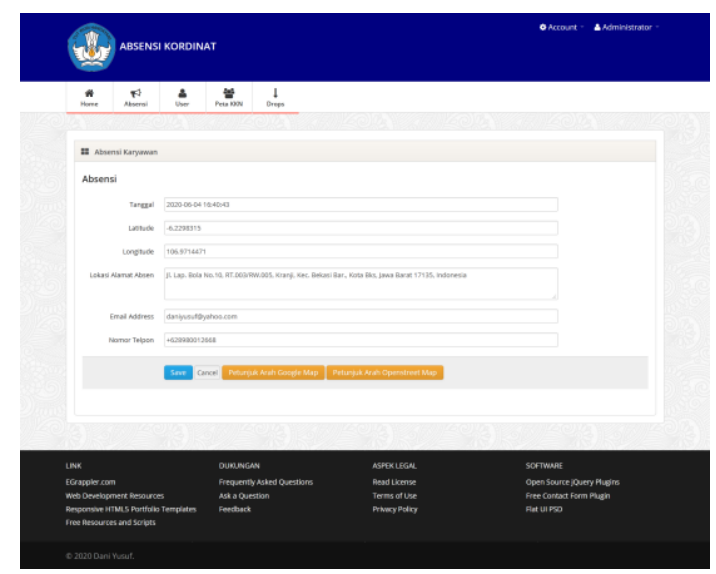

Gambar 14 Kordinat absensi karyawan

\section{Halaman Lokasi Karyawan}

Pada halaman ini staff kepegawaian dapat melihat detail lokasi melalui google map atau openstreetmap. Berikut adalah tampilan lokasi map karyawan menggunakan openstreetmap.

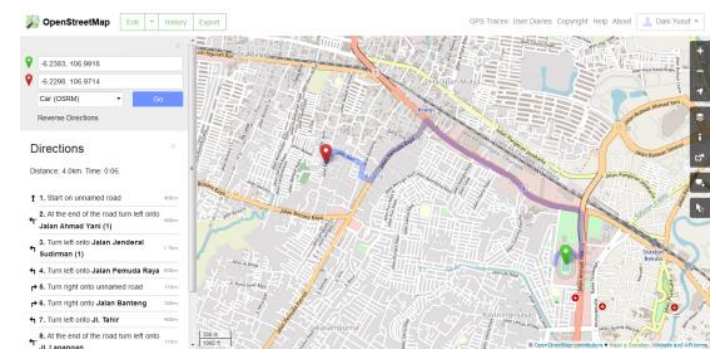

\section{Gambar 15 Lokasi map menggunakan opensteet} map

\section{Halaman User}

Halaman user ini fungsinya adalah untuk melihat user yang telah melakukan register di aplikasi android. Berikut adalah tampilan implementasi register.

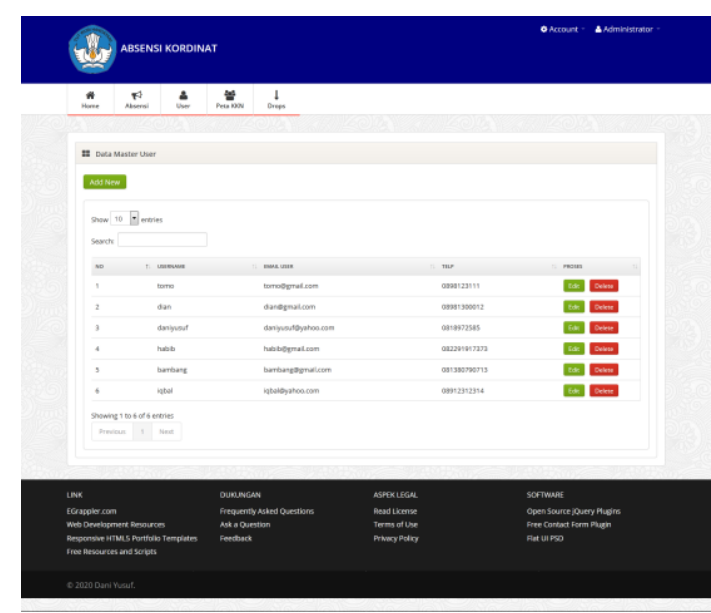

Gambar 16 Halaman user

\section{Kesimpulan dan Saran}

5.1 Kesimpulan

Dari hasil penelitian yang mulai dari perancangan sampai dengan implementasi, maka dapat ditarik kesimpulan sebagai berikut:

1. Dengan membuat aplikasi sistem aplikasi abensi berbasis android menggunakan validasi kordinat lokasi, data kehadiran karyawan dapat termonitor secara realtime, atasan karyawan yang bersangkutan akan dengan mudah mengetahui apakah mereka sudah hadir atau tidak, dan lokasi tempat absen mereka akan terdeteksi.

2. Penyalahgunaan penggunaan absen karyawan akan sulit dilakukan, karena absensi harus dilakukan dari handphone masing-masing karyawan, tidak bisa dititipkan dengan cara mengganti akun login karena validasi dilakukan dengan cara mengambil data lokasi dan nomor kontak handphone yang digunakan.

\subsection{Saran}

Berdasarkan permasalahan-permasalahan yang ada khususnya dalam hal menjalankan sistem aplikasi abensi berbasis android menggunakan validasi kordinat lokasi, maka penulis mengajukan beberapa saran diantaranya adalah:

1. Aplikas diharapkan bisa dikembangkan lagi untuk penggunaan smartphone untuk OS lainnya selain android.

2. Diharapkan aplikasi uji kualitas kain tekstil ini dapat diterapkan di kantor, sekolah, organisasi lainnya untuk mengurangi penyebaran virus covid 19 melalui mesin absensi.

\section{DAFTAR PUSTAKA}

[1]. N. Safaat. Android, "Pemograman Aplikasi Mobile Smartphone Dan Tablet PC Berbasis Android". Bandung: Informatika, 2015. 


\section{Expert}

[2]. Edy dan Ali, "Membuat Sendiri Aplikasi Android untuk Pemula". Jakarta: PT. Elex Media Komputindo, 2014.

[3]. B. Raharjo, "Belajar Otodidak MYSQL (Teknik Pembuatan dan Pengelolaan Database), vol. 1". Bandung: Informatika, 2015.

[4]. B. Hariyanto, "Rekayasa Sistem Berorientasi Objek". Bandung: Informatika, 2004.
[5]. L. P. Dewi, "Pemodelan Proses Bisnis Menggunakan Activity Diagram UML dan BPMN (Studi Kasus FRS Online)," Universitas Kristen Petra, Surabaya, 2012.

[6]. A. B. B. Ladjamudin, "Rekayasa Perangkat Lunak", Yogyakarta: Graha Ilmu, 2006.

[7]. J. Simarmata, "Rekayasa Perangkat Lunak", Yogyakarta: ANDI, 2010. 